\title{
AN ACCOUNT OF QUEEN VICTORIA
}

Paul F. Mattheisen, a graduate student and teaching assistant in the Rutgers English Department, received his M.A. degree from Rutgers in 1956. For his doctoral dissertation, he is working with the Gosse materials in the Symington Collection at the Rutgers University Library.

I

N THE APRIL ISSUE of the Quarterly Review for I 901, less than three months after the death of Queen Victoria, there appeared an anonymous article on the subject of "The Character of Queen Victoria." Among the eulogies which filled the periodicals then, the Quarterly article was distinguished not only for its literary form, but for the author's restraint in telling the distinctly human qualities of an august personage whom reverence had transformed into a near-deity. The emotional intensity of public sentiment at the time made such an attempt to portray the Queen "in the light of truth and the standards of common humanity" not only injudicious but courageous. The article created a sensation. Indignation mounted, and reverberations could be felt in the Court itself. Evan Charteris remarks that "In April I90[I], the attempt hardly escaped the charge of sacrilege." And the author of the article, Sir Edmund Gosse, later described the situation as follows:

Her phantom took divine proportions; she was clothed with the most extravagant and the most incongruous attributes, and any one who endeavoured, in however respectful and even affectionate terms, to separate the fabulous from the historic elements, and reduce the vast idol to human proportions, was regarded as libellous and "cruel." There was an orgy of eulogy, which was perfectly genuine, extremely respectable, and curiously silly. (Edmund Gosse, More Books on the Table. London: Heinemann, I923, pp. 3-4.)

Later biographies of the Queen have often carried judgments more severe than the decorous animadversions of Gosse, who called her "one of the most remarkable personalities of the nineteenth century." But it was Gosse who first put an irretrievable halt to the spirit of uncritical adulation that made an accurate historical account of the Queen impossible. And he succeeded in a performance which at least one American commentator of the time seems to have considered to be impossible. I quote The Bookman here at length not only because

\footnotetext{
${ }^{1}$ Evan Charteris, The Life and Letters of Sir Edmund Gosse (London: William Heinemann, 1931), p. 269.
} 
it sums up the contemporary situation, but also because it unwittingly prophesies the collaboration in which Gosse engaged:

It is much too soon for any one to write of Queen Victoria in the impartial spirit of the philosophical historian; nor, indeed, is it likely that there will ever be set down an accurate and searching estimate of the part which she really played in the great events of her long and glorious reign. In all probability the anecdotes and incidents with which the press has of late been filled are little better than mere myths. Royalty is a sort of cult, perhaps even more in these days than in days gone by; and its secrets are well kept. The few persons who actually know will never tell, for they are themselves an integral part of the whole system, and so their connivance in the fabrication of all sorts of pleasing legends is not only a pious duty, but a matter of self-interest as well. (Henry Thurston Peck, in The Bookman, N.Y., XIII, March I901, p. 82.)

Almost immediately after the publication of the Quarterly article it was conjectured and finally accepted by many people that Gosse was the author. Although he seems never to have denied explicitly his authorship, his shrewd attempts to avoid acknowledgment (see Appendix) suggest that he underwent the proper amount of discomfort. However, his distinguished reputation as a man of letters and his position of authority as a master in the art of literary portraiture undoubtedly did much to lessen his anxiety and to enable him to relish the excitement. No doubt, too, any judgment on his personal guilt was moderated by the recognition that he must have got some information from a collaborator; for Gosse was strictly accurate in his claim: "I never even spoke to the Queen." The presence in the article of information that Gosse himself could not have known delayed for some time the real knowledge that he had written it; but soon it was speculated that he had obtained the aid of an "inside agent," and that this person was none other than Lady Mary Ponsonby, Extra Woman of the Bedchamber, and one of the most respected members of the royal household. Lady Ponsonby was admirably suited to provide Gosse with information on the Queen, since her experience at the Court dated from as far back as March I 7 , I 853, when she was appointed Maid of Honor to Queen Victoria. Although she was obliged to resign this position on the occasion of her marriage to Sir Henry Ponsonby in I $86 \mathrm{I}$, when Sir Henry died in 1895 she was appointed Extra Woman of the Bedchamber. It was her collaboration which made Gosse's article informed and authoritative. 
Since I90I it has quite consistently been assumed that Lady Ponsonby was Gosse's collaborator; it has been known for a fact since the publication of Magdalen Ponsonby's A Maid of Honour in Victoria's Court (1927) and of Evan Charteris' Life and Letters of Sir Edmund Gosse (193I). But the exact nature of Gosse's indebtedness and the way in which the information was conveyed have never been revealed. As late as I 952 Sir Frederick Ponsonby, Lady Mary's son, wrote:

After her [Victoria's] death Edmund Gosse wrote a character sketch of her in the Quarterly Review and this was generally supposed to have been inspired by a conversation with my mother. How far she was responsible for what he wrote I do not know, but of course discussing a person's character in a conversation is a very different thing from writing an article and he probably over-emphasized traits in her character that had only just been touched upon in conversation. I think he really meant to make her out a great personality, but it was too soon to treat her like Queen Elizabeth or Queen Anne and discuss her character as a human being shorn of all glamour that surrounds a sovereign. He appeared to give the impression that she was a person of commonplace ability, which she certainly was not, and his article gave great offence to her friends and admirers. (Sir Frederick Ponsonby, Recollections of Three Reigns. New York: E. P. Dutton \& Co., Inc., 1952, pp. 144-5.)

It is no longer necessary to speculate on this matter; in the light of several new documents evidently unknown to Sir Frederick, we know that there was, in fact, not "a conversation" but a number of discussions and a quantity of letters and notes which Lady Ponsonby wrote to Gosse in I9OI, many of which are still preserved in the Symington Collection at the Rutgers University Library. The correspondence dealing with the article appears to be fairly complete; only a few letters from I9or are missing, although the single letter dated 1903 appears to be a lone survivor from a more copious number. The notes, however, seem to be quite fragmentary, and there are large gaps in the existing pages. Although these notes do suggest the kind of information Lady Ponsonby passed on to Gosse, it is difficult to know how many pages are missing and how much more information was given in conversation. In the Symington Collection there are only four $8 \mathrm{vo}$ pages of notes and thirteen more pages of judicious modifications of debatable passages in the interest of fidelity.

It should be noted that Lady Ponsonby was guilty of no irresponsible disclosures, in spite of the indignation aroused by the article, and 
that Gosse cannot be accused of wanton exaggeration. Lady Ponsonby's attitude towards the Queen was necessarily one of affection and veneration, for she had been among the Queen's sincerest admirers and friends, ${ }^{2}$ and her husband had been the Queen's private secretary for twenty-five years (I 870-I 895). Nothing is more clear from the letters than her determination to be just, and she appears finally to have convinced even the King that the article was complimentary to Victoria. One can imagine that Gosse often must have felt annoyed by such checks on his imaginative genius as are suggested by Lady Ponsonby's remarks: "I feel we have not done justice to the warmth of her personality"; and, "Smart - she hated both the word and the thing." These corrections are not infrequent; at one point Gosse even had to explain to her that large deletions could not easily be made in the proofs. Lady Ponsonby was not content, either, to excuse giving a mistaken impression on the grounds that her information was accurate; sensible that mere fact can often encourage a misleading interpretation, she commends Gosse on the tone of his article, which she felt communicated the proper feeling. Many times she withdrew information she had given, such as that revealed in the Queen's note printed here in the Appendix. She does herself full justice when she claims that hers was "a labour of love."

It also appears from the letters that the charge that Gosse "over-emphasized traits in her character that had only just been touched upon in conversation" can no longer be sustained (the letters, if Sir Frederick Ponsonby knew of them, were not accessible to him in 1952). Not that Gosse was ever willing to submit his independence or to abridge his other sources of information, for even after the article was printed Lady Ponsonby herself did not know his other sources. But it was Lady Ponsonby who kept keen scrutiny over the article at every stage, who made frequent suggestions and corrections, who read and approved the proofs, and who attached her final imprimatur with the remark: "I think the article is really charming." Furthermore, a comparison of the printed article with Lady Ponsonby's existing notes points out clearly that Gosse followed her quite exactly and modulated his tone faithfully, even in some instances making use of her own words; and in many cases where he wholly

2 "There was a real friendship between these two [Lady Ponsonby and the Queen], which lasted till the Queen's death." Magdalen Ponsonby, Mary Ponsonby: A Memoir, Some Letters and a Journal (London: John Murray, 1927), p. xi. 
departs from her phrasing it is usually to give a more literary form to observations she had written in haste. If the letters here printed show Lady Ponsonby's integrity, the finished product reveals Gosse's unwillingness to let literary grace or dramatic heightening interfere significantly with any judgments she expressed.

Not the least interesting aspect of the correspondence is the record it provides of two alert minds secretly enjoying together an ingenious plot and exchanging humorous comments on the confusion they had perpetrated. In many respects, Gosse and Lady Ponsonby were much alike; both were possessors of that rapidity of intellect which Gosse described as a primary requisite for a critic, and both were adept critics of human nature. Their qualities of wit, while different, were mutually congenial. Unfortunately, Gosse's part in the correspondence has to be inferred. We know now that it was Lady Ponsonby who suggested that Gosse write the article using her own notes, but we may also suspect that such an arrangement was precisely what Gosse had hoped for, and we can feel the presence of the epistolary tact for which he was celebrated. We do not know, for example, what happened during the gap in the correspondence between February I 4 and March 4; but somehow Gosse succeeded in overcoming whatever scruple had moved Lady Ponsonby to withdraw her offer of help immediately after it had been made. Even then, it is only gradually that Lady Ponsonby was induced to supply her actual notes, and Gosse must have felt the need for making a careful case for whatever information he needed. No doubt the "committee meetings" helped, for they must have given him the opportunity of exercising the charm that made him one of the most popular men of his time. But Gosse's obvious desire to preserve the correspondence suggests that he wished also to elicit in writing the kind of thing worth preserving, and in this his success is recorded in the letters. We even find Lady Ponsonby sending him an actual autograph note from the Queen revealing information which had been preserved as secret during her lifetime (information which Gosse, at the suggestion of Lady Ponsonby, declined to use in the article).

Lady Ponsonby's compelling personality is revealed so clearly in the letters themselves that little comment is necessary here. I have already mentioned her shrewdness in perceiving human motivations, 
and this characteristic can be seen in her treatment of Mr. Prothero, ${ }^{3}$ the editor of the Quarterly Review. This man seems always to have been hovering outside the inner circle, and Lady Ponsonby seems clearly to have sensed his eagerness to be let in. Aware that he "evidently wished to have supervised the whole matter," but not knowing whether he had actually written any of the article, she speculated wittily that the reason for Prothero's "bitterness" might have been that "his share should not be suspected" by anyone. It was this quality of humor which prevented Lady Ponsonby from taking the affair too seriously. She was, as she says, frightened on one or two occasions, particularly when questioned by the King; and to prevent discovery she was at times careful to leave out information which only she could have supplied, praising Gosse for his skill in concealing his sources. Once she even asked Gosse to burn her letter; but Gosse knew better, and it is to him we owe thanks for preserving the correspondence. She was probably, in fact, less anxious to destroy the evidence than she was to preserve the record: "Pray return the letter, for I feel sure the correspondence will be an amusing one to keep." The words sound prophetic. What Gosse knew was one of the most endearing things about Lady Ponsonby, that she had the ability to enjoy the excitement of the situation. She would, in fact, probably be much entertained at seeing printed a correspondence which is, as she says, "an amusing one to keep."

Lady Ponsonby often wrote in great haste, and she was never overly careful about putting in periods and commas where they were obviously necessary. This is the case so often that I have found it necessary to regularize the punctuation by adding commas, periods and question marks, though I have left in all of her own punctuation. I have not noted the few words that were crossed out or written over. The forms of the addresses and dates have also been regularized, but I have indicated by italics the cases where the address at the top of the page is engraved. Where Lady Ponsonby refers to the name of a person or place simply by using a capital letter, I have used brackets to indicate my contribution. All further alterations are mentioned in the notes. I have referred to Gosse's article "The Character of Queen Victoria" by giving only his name and the page numbers. I

\footnotetext{
${ }^{3}$ George Walter Prothero (1 848-1922), historian and editor. He succeeded his brother as editor of the Quarterly Review in 1899 .
} 
wish to thank the present Baron Ponsonby of Shulbrede for granting me permission to publish the letters of his grandmother, Lady Mary Ponsonby.

Gilmuire, Ascot.

Feb. II, I90I

My Dear Mr. Gosse

I. It was a great pleasure to see your hand writing. 2. I am very sincere when I say that it flatters me beyond expression to think you should think me capable of writing what you suggest for the Quarterly. It is as you say not the first comer who makes the request! I will not waste time over diffident speeches about my inability to do the work satisfactorily but I will tell you as a friend what are the real obstacles to my undertaking it. The fact that I have so much material at hand, that I cannot keep clear of corroborative circumstances to illustrate what I want to say, that in relating these I should find myself quoting and bringing forward personages official and royal who should not be so treated, etc. etc. These facts cut the ground from under my feet and make the task impossible. You will say "but leave out all this doubtful matter." Yes, but what a colourless thing my article would be-perhaps a little better than Lady Jeune: ${ }^{4}$ Even this I doubt, for she has the resource of inventing, which I am debarred from.

Now dear Mr. Gosse, why will you not (perhaps you will?) consider the possibility of writing the article yourself? Then we should get the thing in perfect literary form, and with your instinct, or rather genius, for understanding character, you would with the quantity of really reliable matter which abounds now, the Quarterly would get something worthy of itself. I shouldn't venture, though I can't pretend to say you frighten me very much, to suggest this if I didn't add, that if any thing in some poor notes $I$ have written could be of any use to you, you would be more than welcome to them. I won't try to over sort them or have them type written, but I will bring them to London with me on Friday next and send them on to you if I find a note there to say they might be of use to you.

Yours sincerely

Mary E. Ponsonby

Gilmuire, Ascot.

Feb. I2, I90I

Dear Mr. Gosse

I have reflected on the subject of our correspondence and when I come to think of it, it appears to me that my suggestion is rather impertiment and I hasten to write and beg you to consider it in diss. [sic] phrase as non avenu. I feel my notes would be of no mortal use. I must either have the courage of

4 Possibly Susan Elizabeth Jeune, nee Stewart-Mackenzie (1 843-?), who married the Right Hon. Sir Francis Henry Jeune in 1881 . 
my convictions and sign and publish them or not let them burden any one who would be entangled in them to no purpose.

I hate bothering you and wish I had said this at once, but I was so pleased to think you should have had a favourable opinion of me and had conveyed it to so important a person as Mr. Murray ${ }^{5}$ that I allowed myself to imagine I could justify it. Please forgive me.

\author{
Yours sincerely \\ Mary E. Ponsonby \\ Ambassador's Court, $S$ t James's Palace. \\ ${ }^{6}$ March 4, I 901 . I 2 p.m.
}

Dear Mr. Gosse

I shall appear at 4:30. I will leave Lady Darnley ${ }^{7}$ at the Queen's Council for Nurses at St. Katherine's ${ }^{8}$ [Hospital], where she has often been worsted by having her statements literally accepted.

You will be surprised that I sent you garbage from Stead, ${ }^{\circ}$ but I found him yesterday and for dates and quotations, he is useful. Just look at Rosebery on Granville in $92 .{ }^{10} \mathrm{I}$ put it away at the time thinking it excellent as appreciation of G[ranville]'s two gifts, courage and sagacity.

I also send you-not notes! but mems on court circulars which, with your power of generalisation and selection, may help you to form a judgment on the hidden machinery of the court.

\title{
Yours sincerely \\ Mary E. Ponsonby
}

Have been interrupted in the most maddening way. I think it better you should glance over this tiresome ground before we meet.

${ }^{5}$ John Murray (1851-1928), publisher of the Quarterly Review, grandson of the John Murray who had established the Quarterly in i 809.

${ }^{6} \mathrm{Feb}$. is crossed out, and March is inserted above in pencil, apparently in Gosse's hand.

${ }^{7}$ Florence Rose, daughter of John Stephen Morphy, wife of Ivo Francis Walter

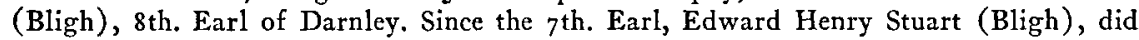
not die until November, Igoo, Lady Ponsonby may be referring to his widow, Jemima Adeline Beatrice.

${ }^{8}$ Queen Victoria's Jubilee Nursing Institute was designed to provide home nursing care for the poor sick of London, and headquarters were set up in several districts of the city. On June 22, I 887 , Victoria was given a Jubilee gift known as the Women's Jubilee Offering, which was a subscription fund contributed by 3,000,000 women of the Realm. A month later the Queen announced that she would use part of the money for a nursing institute.

${ }^{9}$ William Thomas Stead (1849-1912), journalist, founder of the English Review of Reviews in 1890 . He died in the Titanic disaster.

${ }^{10}$ Archibald Philip Primrose, 5th. Earl Rosebery (1847-1929), Foreign Secretary under Gladstone (1886, 1892-94); liberal Prime Minister after Gladstone (1894-95); he led the imperialist faction in the Liberal Party.

George Leveson-Gower, 2nd. Earl Granville ( $1815-1891$ ), best known as Foreign Secretary under Gladstone (1870-74, 1880-85); a distinguished statesman, but was not successful in several important areas of foreign affairs.

See note $\mathbf{I} 2$. 


\section{Mem. on Court Circulars}

Considerations on remarkable men who most have influenced the Queen: L. Granville and Dizzy ${ }^{11}$ opposite types. Ist. born grand seigneur.

Lord Rosebery on his Sagacity. That sagacity (see speech of liberal club $92)^{12}$ took the form in his intercourse with the $Q$ [ueen] of abstaining from any form of wit which would not be apprehended if it were too leste. Coarse, of course, he couldn't be-and he so Bowdlerised his views of life that the Queen looked upon him as a kind motherly chaperone and would have been surprised if she had known what kind of reputation dear Pussy had in other less strict sections of society. There was rather a sense of self protection in guarding his jokes or stories from being divided into 3 heads by the Prince Consort and explained logically. ${ }^{13}$ The other great quality of courage and fearlessness had occasion for exercise at court. A convinced liberal himself of too radical a character to please the Queen if she had discovered it, if there was a question of a friend to be defended he spoke out and with a gleam of the rapier quickly shewed he could not be moved from his standpoint, the attitude being masked afterwards by a vague, benevolent, unconvinced smile and slight purring sound of disagreement which did not offend but elicited (so his correspondence shews) the kind expr[ession] "we must not offend dear Lord G[ranville] by saying anything about (for instance) Mr. Gladstone.” Dizzy too eastern to be vulgar (look out 1868 ). See Stead p. 80. ${ }^{14}$ Something in his solemn and picturesque courtesy which attracted the Queen.

I am afraid I have I 868 at Ascot. ${ }^{15}$. . . word of their lives, and having

11 Benjamin Disraeli, rst. Earl Beaconsfield (1804-1881), Prime Minister in 1868, 1874-80. In the article Gosse writes that the "exquisite manner" of Queen Victoria "was made up of what she had learned as a child from Baroness Lützen, as a girl from grands seigneurs who gently guided her first unpractised footsteps in public affairs, as a young matron from the Prince Consort." Gosse, p. 3 ro.

${ }^{12}$ See London Times, March 24, 1892 , p. Io.

13 "The Queen was partially converted to the Prince Consort's views. . . . But as regards women, she retained her preconceived ideal. She would certainly never have allowed that every action of theirs could be analyzed under one of three categories, as it was said that Stockmar had persuaded Prince Albert to believe." Gosse, p. 327.

${ }^{14}$ W. T. Stead, Her Majesty the Queen: Studies of the Sovereign and the Reign (A Memorial Volume of the Great Jubilee, June 2, 1897). London: "Review of Review's" Office, Mowbray House, Temple, W.C., p. 8o. Lady Ponsonby uses Stead here simply to locate for Gosse an event inadequately explained by Stead. When Disraeli was defeated in his resistance to the disestablishment of the Irish Protestant Church, he immediately sent his resignation to the Queen, who was anxious to keep him in office but was unwilling to dissolve Parliament in order to do so. Disraeli explained that she could refuse his resignation without entailing the dissolution of Parliament, since all parties were anxious to have the electoral appeal made (for the first time) to the new constituencies which had been created by the Reform Bill of $\times 867$, which could not be done for at least six months. In his speech before Parliament on May 5, 1868, Disraeli insisted that the choice was entirely the Queen's (Stead calls this a "maladroit" statement), which brought sharp attention to the personal power of the Queen in such events. There was much resentment, but the Queen benefited from the affair.

${ }^{15}$ Here a page appears to have been lost. The following begins page 5. A passage from 
faithfully kept the secret of their power from the public, it would ill become their friends or descendents to look into the matter and try and discern how they exercised it.

These men gave the Queen their lives without demur or hesitation, and it is as much to her honour as it is to theirs that she inspired such devotion.

Dizzy and Gladstone's appreciation.

The Queen's professional attitude which the practise of 60 years had made a second nature was very apparent in her dealings with religious bodies.

She was the Queen. If the Jesuits at Beaumont College presented her at the Jubilee with the works of Newman, she accepted (under good advice) the present, for was she not the Queen over her Catholic subjects, the Queen head of the Church of Scotland, the Queen of her (interesting) Buddhist subjects, the Queen of her Mohammedan subjects, with never a misgiving that she could be suspected of being a convert to any of these forms of faith.

She felt the responsibility politically, and her intense humaness and lovingness prevented that strong outside expression from degenerating into a hard autocratic rule.

\section{Dear Mr. Gosse}

I am sure that you understood, it was not from any disinclination or laziness that I did not settle to go to my committee yesterday. I am all too sorry the meetings are drawing to a close, but once I made up my mind that your forme - took in every nuance of le fonds, yours, mine and the public's, I could see no reason why I should harass you with more suggestions. I send you I. the rules $\mathrm{H}$ [er] $M$ [ajesty] drew up herself when Sir Henry ${ }^{18}$ became her private secretary, which please return. It is her rough copy. ${ }^{17}$ It will show you how the Queen took the initiative if there was any change in the administration of her affairs, and afterwards simply guided and allowed matters to develop themselves, keeping a sharp look out on the several actors engaged. 2. I have several letters of Gladstone, but this one I 894 seems to sum up the

Gosse may help to explain what Lady Ponsonby has been discussing: "The watchword of the lives of her private secretaries was devotion to the will of the Queen. The secret of the power they exercised was faithfully kept from the public, and will always be kept. These men gave their lives to her service, without demur or reserve, and it is as much to her honour as it is to theirs that she inspired such complete devotion in men of such remarkable gifts." Gosse, p. 33 I.

${ }^{16}$ Lady Ponsonby's husband, General The Right Hon. Sir Henry Frederick Ponsonby (1825-95). After a distinguished military career he became private secretary to the Queen in 1870 , remaining in that appointment until his death. According to Gosse the post of private secretary was instituted by Queen Victoria and never became officially recognized until near the end of her reign.

${ }^{17}$ See Appendix. 
others, and it is useless to multiply testimonials. ${ }^{17} 3$. Dizzy's appreciation is I think well represented in the one saying I gave you on Tuesday. ${ }^{18}$

3 . is the autograph-I will send some others after this stress is at an end for your children's (?) scrap books.

I had a visit from Prothero yest[erday]. Rather a float [sic] face about anonymity being observed, for he evidently wished to have supervised the whole matter. He was very kind and civil. I did not go into details, but said I thought matters were progressing well.

A bell! Hope this will be in time to catch you, before your retreat.

N.B. When you speak of the rather professional check to intimacy in the Queen's friendships please note the paradox that all the same she inspired the warmest and almost fanatical devotion. I feel we have not perhaps given the note of warmth sufficiently.

$$
\begin{aligned}
& \text { Yours sincerely } \\
& \text { Mary E. Ponsonby }
\end{aligned}
$$

St. James Palace.

Dear Mr. Gosse

Saturday Eve, March 9, I90I

I am overtaken in my fib by the apparition of the spectre of the Committee for Queen's Nurses meeting at Londonderry House on Wednesday the I $3^{\text {th. }}$ afternoon at 3.30.- I must attend. What can be done? Do you think you could come here at 5 ? I think we could manage to get in a quiet hour then? but I should scarcely have time to go to Delamere Terrace. ${ }^{19}$

$$
\begin{aligned}
& \text { Yours sincerely } \\
& \text { Mary E. Ponsonby }
\end{aligned}
$$

Dear Mr. Gosse

Sunday, 17 th. March.

I am in a great flurry. I have just receipted a telegram from Count Lechendorff asking me by the Empress Frederick's ${ }^{20}$ desire to come at once to Friedrichshof. A little later she expects all her family, and I suppose this is the only moment she can receive me as for the last year she has intended to do.

I must go, and start with Maggie ${ }^{21}$ on Wedn [esday] morning. I feared it would be Tuesday but I have striven for another day. Since I received this

18 "I believe that General Ponsonby used to be a Whig, but whatever his politics may once have been, I can only say that I could not wish my case stated to the Queen better than the private secretary does it. Perhaps I am a gainer by his Whiggishness, as it makes him more scrupulously on his guard to be always absolutely fair and lucid." Quoted by Gosse, p. 332.

${ }^{19} \mathrm{Sir}$ Edmund Gosse's address from 1876 to $190 \mathrm{I}$.

${ }^{20}$ Queen Victoria's daughter Victoria, Empress Frederick William of Prussia. She was born in 1840 and married Frederick, then Crown Prince of Prussia, in 1858 . She died on August 5, I 90 . I.

${ }^{21}$ Lady Ponsonby's daughter, Magdalen. 
tel[egram] I scribbled two or three notes with reference to Mr. Prothero's suggestions, and now I want to quote from memory a passage or two in your manuscript which I have doubts about.

This is such an unexpected contretemps!

A Mardi-4:30.

\section{Yours sincerely}

Mary E. Ponsonby

Questions on Mans.

I. Is there not a passage about the Q[ueen's] "fluttering eylids"? - It does not convey her look, which was steady, penetrating, soft or severe as the case might be, but not fluttering, which is more French than English.

2. I think the Beaconsfield dinner, Emp[ress] of India, must be left out. On considerations I think I am the only survivor, so the information must come from me. ${ }^{22}$

3. No waving of hands about the jokes I cannot remember, but think there are one or two other details a trifle too personal.

4. I told you the story of the blow with the cane rather inaccurately, and to those who know, the real story is best. It was not on the way to the opera but on her way home from her afternoon drive that in the archway (Constitution Hill I think) the half insane officer with a grievance struck at her with his cane-The ladies were frightened, the Queen said "it is nothing." The ladies and gentlemen in waiting fully expected the going to opera would be put off. But the orders came as usual. The names of those who were to attend and directions to the equerries for carriages, etc. The rest of the story you have all right. ${ }^{23}$

${ }^{22}$ Possibly the account told by Gosse of a florid speech given by Disraeli (Earl of Beaconsfield) after proposing a toast to "the Queen's health as Empress of India." Gosse, p. 334 .

${ }_{23}$ The account of this incident in the Annual Register of World Events ("Chronicle," May, 1850 , pp. 73-4) is as follows:

"Her majesty, accompanied by her children and Lady Jocelyn, had called upon the Duke of Cambridge (who lay ill of his mortal sickness) about six o'clock in the evening. About the same time, and while the carriage was within the gates of Cambridge House, a man, respectably dressed, and to outward appearances a gentleman, was observed loitering about the entrance, and as though waiting for the departure of the Queen. No notice was taken of so common a circumstance as that a gentleman should interrupt his walk for a few minutes in order to see the Queen drive past. A little after six, the carriage drove out, and just as it was passing into the road, and was proceeding at a slow rate to the corner, this person sprang forward, and with a small stick struck a smart blow at the Queen's face. The blow took effect upon her Maiesty's forehead, the bonnet, which was of light texture, being crushed in by the blow. The ruffian was instantly seized by the bystanders; his stick was wrested from him, and he was conveyed to the stationhouse. The Queen proceeded to Buckingham Palace, amidst the cheers of the passers by, and sustained so little injury from this dastardly assault that she was able to appear at the opera in the course of the evening. Upon her Majesty's entrance the opera was stopped, and the national anthem was sung amidst the most enthusiastic cheering.

"The ruffian who made the attack gave his name at the station-house as Robert Pate, of 27, Duke Street, St. James's. . . . At the station-house he refused to give any ex- 
5. A small difference of opinion between you and me. The mot you gave Lord Granville is more elaborate, perhaps better, than he would have given, but not quite him. Just one word in a mild purring tone was sometimes essentially worthy, and was his way.

If any more occurs to me before tomorrow I will note them. I am dining out and writing at full speed-

A. I think this might be insisted upon. The Emp[ress] Eugénie's ${ }^{24}$ visits were a real pleasure to the Queen, and the manner of each to the other perfect.

B. The Queen, while in Florence, greatly enjoyed seeing every beautiful corner of the town and to visit all the churches. She was much pleased at being given permission to see the miraculous picture in the Annunziata. ${ }^{25}$

Intensely interested in the Misericordia ${ }^{26}$ and exasperated at the ladies and gentlemen in waiting succeeding in meeting the procession on their merciful errand. At last, by dint of driving about, she effected the long wished for meeting. "And the poor man was really dead, not only wounded like yours," she observed to one of the ladies. She had scruples in being drawn in her Bath Chair in the churches. "I should hate them to think I was irreverent." A young English Priest who turned up in one of the churches was spoken to by her about this point, and he was transported with joy at this unexpected interview. She was indefatigable in her choice of fresh views to rest before and admire when she camped out for tea. Formerly she sketched during these expeditions, but without attempting this quite lately, she enjoyed the general look of the beautiful country to the end.

C. Her sketches were sometimes very clever, and she followed closely Leach's ${ }^{27}$ teaching. [Illegible word written above the line.] I do not feel the considera-

planation of the motives which had induced him to make his dastardly attack upon the Queen."

On July I Robert Pate pleaded "not guilty." After a trial in which mental derangement was claimed, he was found guilty and sentenced to be "transported beyond the seas for the term of seven years." ("Chronicle," July Ir.)

${ }^{24}$ Eugénie Marie de Montijo de Guzmán, Comtess de Teba (1826-1920), Empress of the French (1853-187I), wife of Napoleon III. On the fall of the French Empire she fled to England (September, I870) and sought the protection of Queen Victoria, with whom she maintained a fifty-year friendship.

${ }^{25}$ Annunziata is the name "by which the Servites are sometimes known, their chief Monastery at Florence, Italy, being dedicated to the Annunciation." (Catholic Encyclopedia, 1907, I, 543.)

${ }^{26}$ The Misericordia is a burial confraternity "believed to have been instituted in 1244 by Pier Bosse," and formed "to carry out the burial of the dead and the friendless as a work of charity." "It is an organization which associates in this work of mercy the members of all ranks of society. Their self-imposed task is not limited to escorting the dead to their last resting-place, but they discharge the functions of an ambulance corps, dealing with accidents as they occur and carrying the sick to the hospitals. When on duty the members wear a dress which completely envelops and disguises them. Even the face is hidden by a covering in which only two holes are left for the eyes." (Catholic Encyclopedia, 1908, III, 78.)

${ }^{27}$ Unidentified. 
tion of the Queen's drawings can be discussed as a serious question of art. It seems to me that it is out of place to put this accomplishment under the heading of her attitude towards art. An interesting note may be made on the fact that the $\mathrm{Q}$ [ueen] has left her drawings to the library at Windsor, thus claiming a historic place in the traditions of Windsor-

D. The Queen acknowledged the work required of her in Dublin was twice as great as in her visit in I 853 ? She thoroughly believed the Irish loved her. The wit and gaiety of the crowd delighted her-in her heart she preferred the Celtic races. She felt the stimulus of succeeding in pleasing when she tried to win the Irish, but the fatigue and strain was [sic] very great.

E. It is impossible for any one well acquainted with the $\mathrm{R}$ [oyal] family to enter on the difficult ground of the Queen's relations with her own familyHer devotion to all her children was undoubted, and to analyse which of the nine called out the deepest expression of this devotion, would be invidious, even if it were practicable. But of her affection for $\mathrm{P}$ [rince] Henry of Battenberg ${ }^{28}$ and her deep, overwhelming grief at the death of Prince Christian Victor, ${ }^{29}$ too much cannot be said. Certainly this sorrow and the sympathy she felt for those of her friends who had lost dear ones in the war, crushed her more than was supposed, but never for one moment did she waver in her conviction that the war was a righteous one. She was loyal to the Gov[ernment] even to excess, and though praying for peace and hating bloodshed, her words of encouragement and support were ever at hand to encourage her ministers.

That she regretted she had not seen the end of the war was true, but that she wished it to be arbitrarily stopped was one of those lies which work unspeakable mischief because her humane expressions might be distorted into plausible support of the antipatriotic jargon rampant at one time.

The routine of the Queen's day may be found almost anywhere.

\section{Dear Mr. Gosse}

Lord Wardens Hotel. Tuesday Eve

Such a howling night, but there is something rather exhilarating in facing the world tomorrow-

A nuance

I told Mr. P[rothero] that I agreed with all his improvements, and on two or three points I differed-and he may wonder what it means. My notes on this are rough and tiresome, but do you think he had better see them?

Have we said enough about Prince Consort; her seclusion and then renaissance after Jubilee. I am dead tired.

Yours sincerely

Mary E. Ponsonby

${ }^{28}$ Beatrice, Queen Victoria's youngest daughter, married Prince Henry of Battenberg on July 23, 1885. The Prince died on January 20, 1896.

${ }_{29}$ The Queen's grandson, Prince Christian Victor of Schleswig-Holstein, eldest son of Princess Helena, Victoria's second daughter. He died on October 29, 1900. 
Dear Mr. Gosse

Brussells.

Sunday, March 3I, I 90 I

Mr. Prothero has sent me the proof; it requires very little alteration, and I think the skill with which you have worked in all the threads of your material in such a masterly way that the texture is absolutely perfect and it is impossible to guess from whence you have derived your information.

Don't tear the other page, as I begun at the wrong end by mistake-I wonder whether you got my telegram about the head nurse's forgotten dress! The indignation about Mr. Crawford's' $\mathrm{s}^{30}$ not perceiving how "beautiful dear Mama's dress was" caused me to quake in my shoes.

I must answer Mr. Prothero, but I must refer him to you. We go back to London I think on Monday, probably Tuesday, so please send me a line to St. James to say if now all is straight and we meet in future as friends and not collaborateurs!

$$
\begin{aligned}
& \text { Yours sincerely } \\
& \text { Mary E. Ponsonby }
\end{aligned}
$$

Lützen or Letzen? p. 2. Most likely you are right. ${ }^{31}$

I. Strange that her household p. 4 were not either harassed or tried, for when she was ill, she was often more original than at any other time.

2. She never admitted she was wrong. This appears to me to be far too absolute. If it were proved she had made a mistake, note the candour and frankness with which she would say- "Lord A, B or C said he thought I was wrong, and so it has turned out."

3. P. 9 I 2 you have the correct anecdote.

I found the other day at Friederichshof that Mr. Crawford's ill natured remarks about the Queen's dress were much resented--and I made a note to cut out the passage I have marked p. 9.

[Several pages missing.]

I6. Smart. She hated the word and the thing. [Written in red pencil at the top of the page. Beneath it, the following sentence continues from a lost page:] ... additions, I find Mr. Prothero does not know of the amendments we made to his suggested additions, and in my answer to his letter I have referred him to you. I am afraid of quoting from memory or we shall have three or four authorised versions.

${ }^{30}$ Unidentified.

${ }^{31}$ Fräulein Louise Lehzen, afterwards Baroness, was the daughter of a Lutheran clergyman of Hanover, and governess to Princess Feodore, eldest daughter of the Duchess of Kent. She became governess to Queen Victoria in I 824 , was created Hanoverian Baroness in 1827 , and retired to Hanover in 1842 . She remained the Queen's close friend until her death in 1870 , when the Queen wrote: "She knew me from six months old, and from my fifth to my eighteenth year devoted all her care and energies to me with most wonderful abnegation of self, never even taking one day's holiday. I adored, though I was greatly in awe of her. She really seemed to have no thought but for me." Quoted in Sidney Lee, Queen Victoria (London: Smith, Elder \& Co., 1904), p. 20. 
Ambassador's Court, $S^{t}$ James's Palace.

Tuesday, April 2, 190 I

Dear Mr. Gosse

I have just returned and am at this moment quite rompue! However deeply interested in the corrections of the proof, I quite see what you mean about the necessity of supplementing, if we cut-The only bit I am frightened about is the perfectly true and accurate description of the method of work by means of which the private Secretaries noted, scheduled and advised upon the despatches which went through their hands. This is perfectly true and interesting, but I think it would be resented as shewing up a system which had always been disowned.

I am here till Saturday. Could you come Thursday either for dinner, no family, or after dinner, or let me go to Delamere Terrace on Friday 5 o'clock?

\author{
Yours sincerely \\ Mary E. Ponsonby
}

Gilmuire, Ascot.

April I8, 1901

I ought to write this untidy letter again, but people have flocked to luncheon and I am dazed!

\title{
Dear Mr. Gosse
}

I can't help thinking Mr. Prothero leaves this question of remuneration to be settled between ourselves. At all events, I will tell you something of the impasse in which I find myself. In the first place I do not honestly think in any case I am entitled to half the fee, as the labour and inconvenience have fallen far more heavily on you than on myself. But, after compliments, as they say in the East, I will go on to my own personal feelings against accepting any thing for my work, which has really been a labour of love.

Not that I should refuse the offer on general principles. I should really be glad to have earned it, but shortly, these are my difficulties. I cannot consent to do the mean thing of waiting to see if I escape blame before I accept the fee. If I am detected, I should be unable to say, what in fact is the literal truth, that I have nothing to say to the authorship, that there is a deal of matter in the article which is unknown to me, and a great deal perfectly known, not only to me but to many others whose memory goes back far enough, etc.- and all the time be taking my share in the venture.

I am sure you see now why I had better decline. What shall I do about writing to Mr. Prothero? Do you think you could explain the matter to him in a few words? You have been so extraordinarily kind and thoughtful in un- 
derstanding my hesitations and tiresome corrections, that I know I can rely on your interpretation of my scruples to Mr. Prothero and of my wish, in spite of yours, to ask you the favour, regardless of your dislike to this solution of the difficulty, to be the only acting partner in our firm, which is now settling its accounts, and accept the whole fee?

$$
\begin{aligned}
& \text { Yours very sincerely } \\
& \text { Mary E. Ponsonby }
\end{aligned}
$$

$$
\begin{aligned}
& \text { Gilmuire, Ascot. } \\
& \text { Wednesday, [April] 20, I901 }
\end{aligned}
$$

I am rompue after two days in

London. Please burn this.

\section{Dear Mr. Gosse}

Yes I am rather frightened! I was asked from the King whether I had written the article, and answered "Certainly not, but I thought it very good." What is ingenious in the situation is that $I$ am able to be eloquent in praise of the literary value of the article due to you, and you can expatiate on the curious interest of the new facts revealed to the public - Bref [briefly?] it is very amusing, and I don't see why the secret, which will promptly be uninteresting and out of date, should ever be known.

I heard there was a heated discussion in the lobby of the House of Commons carried on by Mr. Harcourt, Bobby Spencer, Asquith, and John Morley as to the authorship. ${ }^{32}$ The first asserted he knew by internal evidence it was by me, the others denying it! Then the Bishop of Winchester at Sandringham $^{33}$ said he was convinced it was mine. The K[ing], more shrewd, said "if by a lady, then certainly it is Lady $\mathbf{P}$ [onsonby]. Otherwise it is by a clever man who has got hold of the facts." Please burn this. I wish we could meet. It would be so amusing.

\section{Yours sincerely Mary E. Ponsonby}

${ }^{32}$ Sir William George Granville Venables Vernon Harcourt (1827-1904), former Home Secretary (1 880-85) and Chancellor of the Exchequer (I 886, I 892-94, I 894-95), in 1901 a private M.P. Charles Robert Spencer, 6th. Earl Spencer, Viscount Althorp, Parliamentary Groom in Waiting to the Queen (1886) and Vice-Chamberlain (1892-95). Herbert Henry Asquith, Ist. Earl of Oxford and Asquith (1852-1928), former Home Secretary (1892-95), Chancellor of the Exchequer (1905-08), and Prime Minister (1908-16), in I901 liberal M.P. John Morley, Viscount Morley of Blackburn (1839I 923 ), statesman and writer, M.P. from 1896 to 1908.

${ }^{33}$ Randall Thomas Davidson (1848-1930) was ordained Bishop of Winchester in 1895 and Archbishop of Canterbury in 1 903 . He was appointed Dean of Windsor and domestic chaplain to the Queen in 1883 . 
Gilmuire, Ascot.

April 23, I90 I

\section{Dear Mr. Gosse}

Well - - - Yes, or Yaaas, as Maggie says, which Henry James says is equivalent to "yes, ass, for asking the question!" To leave Barloonery ${ }^{34}$ aside, now the dilemma has assumed another shape. I don't like to jouer le beau rôle and to force you to take the sordid one without explanation. If Maggie is to take me abroad with my spoils, which I know she will suggest, will you not confide the subterfuge to Prothero? He writes today that, as he sees it is my wish, he will send you the whole fee. He adds there is a report the article is by a bishop who was on confidential terms with the $Q$ [ueen] (I wonder which of us two deserves the halo of sanctity most?), or a Radical Statesman, both guesses at all events wide of the mark! Write me one line to say what you think of Scrup[le] II, and don't send the cheque to the charity!

\section{Yours sincerely}

Mary E. Ponsonby

I think the article is really charming.

\section{Dear Mr. Gosse}

$$
\begin{aligned}
& \text { Gilmuire, Ascot. } \\
& \text { May 5, I90I }
\end{aligned}
$$

I hear you acknowledge the authorship of the article! I think it is a very good thing because, besides being true, it stops the discussion on the subject, which is becoming tiresome. But you will keep my secret won't you? Because not only am I committed to emphatic denials, but I have caused my sons to back me up in this line, and it would make them feel very foolish if I now turned rounde. ${ }^{35}$

Send me a line to reassure me!

I am so glad the Quarterly has had a success. It touched a vein of gossip which was sure to tell.

34 Possibly a term deriving from the Baring family's private vocabulary. Maurice Baring was Lady Ponsonby's nephew.

${ }^{36}$ Gosse replied on May 6: "I am very much puzzled at your having heard that I 'acknowledge the authorship' of the article. I have not.

"Mrs. Ady (Julia Cartwright) knows the Murrays very well, and she told her brother, who is in the F.O., that I have written it, and he challenged me. I replied that I never even spoke to the Queen. He told his sister, who replied that 'that was all nonsense,' for she 'knew I had.' And he added that your son Arthur said he knew I did it. Then I shrugged my shoulders. This is the only way in which I can guess that it has come out. And now, at all events, it seems to have gone in again, for it is published authoritatively to-day that Sir Theodore Martin is the author." Quoted in Magdalen Ponsonby, Mary Ponsonby. A Memoir, Some Letters and a Journal (London: John Murray, 1927), pp. 207-208. 
You will meet $B$ [etty] Montgomery ${ }^{38}$ at Taplow. She is disappointed the article is not by me so please be careful with her.

\author{
Yours sincerely \\ Mary E. Ponsonby
}

[For letter dated May 7, see Appendix.]

Dear Mr. Gosse

Gilmuire, Ascot.

May 30, I90I

As far as I am concerned, I am quite content you should be considered to be the author of the article; besides, it is gospel truth, and if Mr. Prothero looks back to our former correspondence, he will find the very expressions used by me, i.e. your discrimination, sense of values in statements, and inimitable gift of literary construction, are in this American article ${ }^{37}$ and that was my reason for asking the favour of your collaboration. I am sorry for the title to the article in A [merican] newspaper, for it makes it difficult to ignore, but $I$ shall say: "I see they now say it is by Edmund Gosse, and when I come to think of it-it is very like his way of writing." As for your betraying me, I wrote in answer to Mr. Prothero's letter of apology for my secret having been betrayed, that I was quite certain you had never given me away, but that I only had to thank my friends who pronounced in the most trenchant way as to their absolute certainty from "internal evidence" (I am so sick of the phrase) that some passages could only have come from me, etc., etc. Then jealous friends suggested doubts, "as the Q[ueen] had never liked me," etc., etc. Mr. Knowles ${ }^{38}$ I am rather angry with, as if I had obtained leave (which was refused[)]. I promised to write for him an article on Loyalty at the time of the Jubilee, and I think it ungenerous of him, as I refused to give him my notes this time, to say he knew they existed. I must say, people in my own immediate surroundings have acknowledged that my answer-" II did not write the article, I think it excellent and wish I had written it," must be accepted. I am extremely sorry you have been so badgered, and I think we shall both rejoice when we step out of this Gueppier and are left in peace. Please tell me if any of the article is Mr. P[rothero]'s. This may account for some of his bitterness, that his share should not be suspected. Many thanks for writing to me-Please keep this letter to yourself, or rather burn it.

Yours very sincerely

Mary E. Ponsonby

\footnotetext{
${ }^{36}$ Maj.-Gen. William Edward Montgomery (1847-1927) married Alberta (Betty), Lady Ponsonby's daughter, in $189 \mathrm{I}$.

37 Unidentified.

${ }^{38}$ Sir James Thomas Knowles ( $83 \mathrm{I}-1908$ ), architect and editor. He edited the Contemporary Review (1870-77) and founded and edited Nineteenth Century (1 877I 908 ).
} 
Gilmuire, Ascot.

Dear Mr. Gosse

$$
\text { May 31, Ig0 I }
$$

What is this barloonery? Pray return the letter, for I feel sure the correspondence will be an amusing one to keep. But we are all getting unhinged! You-calling me Lady Prothero.

Prothero-wondering where a letter of mine is which I never wrote and which he says is in Spain.

I because I am getting énnervée.

\author{
Yours sincerely \\ Mary E. Ponsonby
}

Dear Mr. Gosse

St. James.

June 6th.

I am more than sorry to trouble and worry you again, but the exact thing has happened that I wished to avoid, and which I foresaw might occur if $I$ denied my share of the authorship in $Q$ [uarterly] $R$ [eview] and yet was tempted to listen to an offer of remuneration.

My sister in law, Mrs. Baring, ${ }^{38}$ tells me that she has heard, and her friend says she has received it from indisputable authority, that Mr. Gosse and Lady Ponsonby met frequently to arrange the article between them, Lady Ponsonby writing nothing, but speaking from notes. Moreover, Mr. Gosse handed to her one-half the fee he received. As it is literally true I can say nothing, but I can make it untrue. First I will dispose of the indirect cheque to $M$ [aggie]. Secondly I must utterly refuse any thing more.

There is a Queen Victoria Memorial fund for the Queen's Jubilee Nurses. I have been on the council since my husband established it in 1894 , and am deeply interested in the extension of the scheme.

Now do you think Mr. Prothero, or rather Mr. Murray, would consent to sending my share of profits, if indeed there is any question of such a thing being offered me, "From the Quarterly Review" to the Queen's Memorial, without names or explanation?

Will you manage this for me?

In tremendous haste,

\title{
Yours sincerely
}

Mary E. Ponsonby

I will send you papers of memorial.

${ }^{39}$ Lady Mary's sister, Louisa Emily Charlotte Bulteel (d. 1892), married Edward Charles Baring, ist. Lord Revelstoke, in I $86 \mathrm{I}$. The "sister in law" would possibly be the wife of one of Baring's brothers, Evelyn Baring, Viscount Cromer (married Ethel Errington) or William Frederick (married Emily Jenkins). 
Please return. E.G. [In Gosse's hand.]

Dear Mr. Gosse

The modesty of the sum prevents any violent scruples from worrying me, but I keep up the subterfuge of leaving you in communication with Maggie. The other day an irritable friend said to my sister in law- "There is one sure way of solving the mystery of the authorship of this art[icle]. Your sister in law must know if she received a cheque of $\mathfrak{E}_{500}$ or not." I answered, "Certainly I should know, and moreover if I do I will tell your friend." In fact, I have never believed in the fabulous gains of the $Q$ [uarterly], and it seems I was right, but I am rather curious to know what the truth is.

I have much to say to you about Maurice. I am so enchanted with what I have seen of his play. ${ }^{40}$ If I don't let, which I fear I must do, I hope you will pay me a little visit. In this tropical weather the air under the fir trees is delicious.

$$
\begin{aligned}
& \text { Yours very sincerely } \\
& \text { Mary E. Ponsonby } \\
& \text { Ambassador's Court, } \\
& \text { St James's Palace. } \\
& \text { Feb. I 7, 1903 }
\end{aligned}
$$

Dear Mr. Gosse

No, your Dowager Lady R [adnor] ${ }^{41}$ is safe out of Ethel's ${ }^{42}$ way, but she does know a good deal about music, which the reigning Lady (née Julian Balfour) does not. I am very much preoccupied about Maurice Baring. It must be his diplomatic work that has been found wanting, because he has not begun his foreign office turn of work. ${ }^{43} \mathrm{I}$ don't think he intends to try going back to diplomacy, but I have not asked him because all that family have a way of putting on suddenly what we call the "shut door Baring manner" and then one is left out in the cold. I have been reading his last

40 The author Maurice Baring was Lady Ponsonby's nephew, being the son of Lady Revelstoke, Lady Ponsonby's sister. The play is probably Dusk, which she mentions in the following letter. There is a single vertical line struck through this paragraph.

${ }^{41}$ Helen Matilda, wife of the 5th. Earl Radnor. Their son, Jacob Pleydell-Bouverie, 6th. Earl Radnor (1868-1930) married Julian Balfour, daughter of Charles Balfour, in 1891 .

42 Dame Ethel Smythe (1858-1944), composer and writer, close friend of Lady Ponsonby. She writes at length of Lady Ponsonby in $A s$ Time Went On ... (New York: Longmans, Green and Co., 1936).

43 "In 1904 I decided to abandon the diplomatic career and to take up journalism." Maurice Baring, in Taventieth Century Authors, ed. Stanley J. Kunitz and Howard Haycraft (New York: H. W. Wilson Co., I942), p. 7 I. 
play $D u s k^{44}$ and like it much better than I did when I first made the plunge. His literary friends (you?) tell him it is by far the best thing he has done. I think I gave you rather a wrong impression of what I said when questioned by headquarters (the King) about the Quarterly.

Bref [briefly?] I said I did not write it and wished I had, but perfectly owned to being the source of some of the stories, not one of which did I see was derogatory to the Q[ueen's] reputation. I will send you the Eugénie story out of Max Müller. ${ }^{45} \mathrm{I}$ have been really very bad for 24 hours, and haven't left my room. I have missed a charming dinner at John's and one at the Spencers. ${ }^{46}$ I seldom indulge in a lark, and am quite provoked when it does not come off. I hope you may be persuaded to meet my daughter Mrs. Mont[gomery] at luncheon some day soon. I have heaps more to say!!

Yours sincerely Mary E. Ponsonby

\section{APPENDIX}

[The following are documents which exist in the form of typed copies in the Symington Collection. Lady Ponsonby's letter is taken from a transcription by Alexander Symington. The note from the Queen and the letter from Gladstone are further removed from the originals, being Symington's transcriptions of copies evidently made by Gosse. Since I have not seen the autographs, I print the transcripts in an Appendix only because Lady Ponsonby mentions them in her letter of March 7, I90 I. I have not made any corrections or alterations in the texts.]

Gilmuire, Ascot.

May 7 , 190I

\section{Private}

Dear Mr. Gosse,

As you say the scare has subsided and I think everything is safe. This is the sentence in Arthur's ${ }^{1}$ letter which frightened me. . . . "other think it is

\footnotetext{
${ }^{44}$ For a discussion of this "dramatic poem" see Ethel Smythe, Maurice Baring (London: Heinemann, 1938), p. 64.

${ }^{45}$ Friederich Max Müller (1823-1900), naturalized British citizen born in Dessau, Germany. He was perhaps best known for his work in Oriental linguistics and his mythological studies. For the story about the Empress Eugénie see his Auld Lang Syne, first series (New York: Charles Scribner's Sons, r 899), p. 208. Gosse used the story in his article, p. 313.

${ }^{46}$ See note 31 to letter dated April 2o. "John" is probably John Morley.

1 Probably Lady Ponsonby's son, Arthur Augustus William Harry Ponsonby (I 871 I 945), later Ist. Baron Ponsonby of Shulbrede.
} 
by Arthur Benson ${ }^{2}$ but I saw a friend of E.G.'s who believed the whole thing with me and told me that E.G. makes no mystery about having written it. I think he is right. . . . Well your letter explains how it came about.

\section{Private.}

Re. the King.

He was doubtful at first, "shewed too intimate a knowledge", and "discussed the Queen's feelings" etc. but believing it to be by me, he said I was the only Lady of the Court capable etc.

Then came my denial and that there were some things in the article I didn't agree with and other excellent passages relating things I had not before heard of. That I should say it was by far the best notice of the Queen and the most interesting that had appeared. That as for the literary form and finish of it I only wish I were capable of writing anything half so good. That I didn't agree about the spirit of criticism-it appeared to me the note was appreciation not criticism. All this not directly addressed to H.M. but through Fritz $^{3}$ who I affected to think had not been given a message to me but had been "told to find out."

My answer more than answered the purpose for I am told he is much pleased with it, the art., so you must be on the look out that he does not question you as to who your collaborateur is. You will have to fall back on Prothero and others. It is really fast turning into a storm in a tea cup!

Re. Sir W. Harcourt. ${ }^{4}$

He was a great friend of mine in the fifties so probably knew some of the stories about the ladies in waiting etc. I think it shews bad taste to insist upon pursuing the matter if it annoys me. I feel you must be rather bored with the whole thing but I think our pleasant committee meetings will always be a pleasant remembrance for both I hope!

Yours very sincerely

Mary E. Ponsonby

\section{9, Delamere Terrace \\ Westbourne Square, $W$.}

Copied from the Queen's autograph, lent me by Lady Ponsonby, March 7, Ig01. E. G.

$$
\begin{aligned}
& \text { Windsor Castle, } \\
& \text { April I, } 1870 .
\end{aligned}
$$

With respect to the arrangements consequent on the sad loss of poor General

2 Arthur Christopher Benson (1862-1925), author, editor of the Correspondence of Queen Victoria (1907). At this time he was master of Eton.

${ }^{3}$ Lady Ponsonby's son, Col. the Right Hon. Sir Frederick Ponsonby, 2nd. Baron Sysonby (1 $867-1935)$.

${ }^{4}$ See letter April 20, 1901. 
Grey ${ }^{5}$-the Queen would wish to say a few more words in addition to what she said yesterday to Sir Thomas. ${ }^{6}$ I. She thinks that Sir Thomas should make any suggestions which he thinks would facilitate matters as to how the business should go on, - whether he would keep, for the present, Army and Navy Matters in his own hands-that is:-let the communications pass between him and the Ist. Lord and C. in Chief, (keeping Col. Ponsonby fully informed of it all and talking it over with him) -till at any rate he has been some time in his new Office. 2. Sir Thomas should explain to Col. Ponsonbythat she wishes him to read thro' all the Despatches she sends down-and always to turn the Labels and send them back to the Offices, etc. When the Queen asks for abstracts Mr. Bell or Mr. Langdon ${ }^{7}$ should make them, as heretofore-tho' Col. Ponsonby should see the last important papers on subjects of interest and on which there have been correspondence-Prussian Disarmament-Germany-the Army, \&c. \&c. Sir Thomas, the Queen believes has seen the greater part of the last important correspondence on the Army? 4. Both Sir Thomas and Col. Ponsonby should keep watch on what goes on in and out of Parliament and draw the Queen's attention to any questions which affect the prerogative, or the Army, Navy, - or in short anything, - so that should the Queen not have been informed or asked, she can ask for explanation, or remonstrate. This is of the utmost importance for the Queen has not the time to watch everything and is sadly overworked and is so often unwell now as to require much help. In the same way if anything in the Despatches, private Letters and Draft of importance strikes Sir Thomas and Col. Ponsonby they should call the Queen's attention to it.

In the present day when the old Traditions are being more and more lost, the Queen feels it of the utmost importance that the greatest watchfulness should be exercised.

Would Sir Thomas communicate this paper to Col. Ponsonby and let him have a copy of it?

He should never hesitate to ask to see the Queen if he is in any doubt about anything.

V.R.

P.S. The Queen will also repeat here the great necessity for her P. Secretary's being extremely discreet, never to let his own Political feelings be known to others, or to appear to belong to any Party.

${ }^{3}$ General Charles Grey (1804-1870), private secretary to Queen Victoria until his death. He was succeeded in this post in 1870 by Lady Ponsonby's husband, Sir Henry.

${ }^{6}$ Sir Thomas Biddulph (1809-1878), who succeeded Sir Charles Phipps as Keeper of the Privy Purse. Gen. Ponsonby succeeded him in 1878 .

$\tau$ "In the Privy Purse office in London Mr. D. Courtenay Bell, selected originally by the Prince Consort as an assistant, held the position of Permanent Secretary from 1876 to 1888 . He was an F.S.A. and author of historical books on London." Arthur Ponsonby, Henry Ponsonby, Queen Victoria's Private Secretary (New York: The Macmillan Co., 1944), p. 57. Langdon unidentified. 


\section{9, Delamere Terrace}

Westbourne Square, W.

Copy of letter from Mr. Gladstone, lent me by Lady Ponsonby, March 7, I90I. E.G.

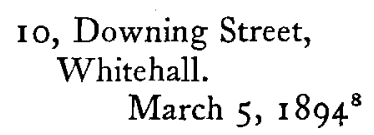

My dear Sir H. Ponsonby

The first entrance of a man to Windsor Castle, in a responsible character, is a great event in his life; and his last departure from it is not less moving.

But in and during the process which led up to this termination on Saturday my action has been in the strictest sense sole, and it has required me in circumstances partly known to harden my heart like a flint.

However it is not even now so hard but that I can feel what you have most kindly written: nor do I fail to observe with pleasure that you do not speak absolutely in the singular. If there were feelings that made the occasion sad, such feelings do not die with the occasion.

But this letter must not be wholly one of egotism. I have known, and have liked, and have admired, all the men who have served the Queen in your delicate and responsible office; and have liked most, probably because I knew him most, the last of them, that most true-hearted man, General Gray. But forgive me for saying you are "to the manner born:" and such a combination of tact and temper with loyalty, intelligence and truth I cannot expect to see again. Pray remember these are words which can only pass from an old man to one much younger though trained in long experience.

Believe me always and most sincerely yours,

\section{W. E. Gladstone.}

${ }^{8}$ Written on the occasion of Gladstone's final retirement from political life. For a discussion of Sir Henry's part in this matter, and for other letters, see Sir Frederick Ponsonby, Side Lights on Queen Victoria (New York: Sears Publishing Company, 1930), pp. 377-400. This letter is printed in several places. See Arthur Ponsonby, Henry Ponsonby (London: Macmillan \& Co., 1942), p. 263. I reprint the letter here in order to bring together the documents referred to by Lady Ponsonby. The text differs slightly from that printed by Arthur Ponsonby. 
Lord Warden Hotel Lear In Gore Tuesday \&f Suck a howling night but there is somelticy rater sehbletating in facing the floors Tomorrow -

A nuance

$\checkmark$ told W P. Hat I arad wits all his improvements $\alpha$ on two o on thee points differed - $\alpha$ he may louder what it means. Bey notes on the are sough \& Terecoul. but do you thine he has better see the ne?

Have we raid enough about Pruner Consort. her techuion \& Then renairsare after tulle 1 au dea? here - gpu MS P

A Note from Lady Mary Ponsonby to Edmund Gosse, Probably Written Shortly Before the Publication of Their Article. 